\title{
Rho iso-alpha acids from hops inhibit the GSK-3/NF- $\kappa$ B pathway and reduce inflammatory markers associated with bone and cartilage degradation
}

\author{
Veera Reddy Konda*, Anuradha Desai, Gary Darland, Jeffrey S Bland and \\ Matthew L Tripp
}

Address: MetaProteomics Nutrigenomics Research Center (a subsidiary of Metagenics, Inc), 9770 44th Avenue N.W., Gig Harbor, WA, 98332, USA

Email: Veera Reddy Konda* - vrkonda@metagenics.com; Anuradha Desai - anudesai@metagenics.com;

Gary Darland - garydarland@metagenics.com; Jeffrey S Bland - jeffbland@metagenics.com; Matthew L Tripp - matthewtripp@metagenics.com

* Corresponding author

Published: 27 August 2009

Journal of Inflammation 2009, 6:26 doi:10.1186/1476-9255-6-26

This article is available from: http://www.journal-inflammation.com/content/6/1/26

(c) 2009 Konda et al; licensee BioMed Central Ltd.

This is an Open Access article distributed under the terms of the Creative Commons Attribution License (http://creativecommons.org/licenses/by/2.0), which permits unrestricted use, distribution, and reproduction in any medium, provided the original work is properly cited.
Received: 28 January 2009

Accepted: 27 August 2009

\begin{abstract}
Background: Rho iso-alpha acids (RIAA) from hops have been shown to have anti-inflammatory properties. To understand the mechanisms, we evaluated the effect of RIAA in cell signaling pathways and inflammatory markers using various in vitro models. We also investigated their therapeutic effect in mice with collagen-induced arthritis.

Methods: The LPS-stimulated RAW 264.7 macrophages were used to evaluate the effect of RIAA on the NF-KB and MAPK signaling pathways; phosphorylation of ERKI/2, p38 and JNK was assessed by western blotting and NF- $\kappa B$ binding by electrophoretic mobility shift assays. Effect on the NF$\kappa B$ activity was evaluated by the luciferase reporter assays in LPS-stimulated RAW 264.7 cells. GSK$3 \alpha / \beta$ kinase activity was measured in cell-free assays. The inhibitory effect of RIAA on inflammatory markers was assessed by measuring nitric oxide in LPS-stimulated RAW 264.7 cells, RANKLmediated TRAP activity in transformed osteoclasts, and TNF- $\alpha / \mathrm{IL}-\mathrm{I} \beta$-mediated MMP-I3 expression in SWI 353 cells. Mice with collagen-induced arthritis were fed with RIAA for 2 weeks. Symptoms of joint swelling, arthritic index and joint damage were assessed.

Results: RIAA selectively inhibited the NF-KB pathway while having no effect on ERKI/2, p38 and JNK phosphorylation in LPS-stimulated RAW 264.7 cells. RIAA also inhibited GSK-3 $\alpha / \beta$ kinase activity and GSK-3 $\beta$ dependent phosphorylation of $\beta$-catenin in RAW 264.7 cells. In addition, RIAA inhibited NF- $\kappa B$-mediated inflammatory markers in various cell models, including nitric oxide in LPS-stimulated RAW 264.7 cells, RANKL-mediated TRAP activity in transformed osteoclasts, and TNF- $\alpha /$ IL-I $\beta$-mediated MMP- I 3 expression in SWI 353 human chondrosarcoma cells. Finally, in a mouse model of collagen-induced arthritis, RIAA ameliorated joint damage as evidenced by significant reduction of the arthritis index and histology score; at $250 \mathrm{mg} / \mathrm{kg}$-body weight, RIAA had efficacy similar to that of $20 \mathrm{mg} / \mathrm{kg}$-body weight of celecoxib.
\end{abstract}

Conclusion: RIAA may have potential as an anti-inflammatory therapeutic. 


\section{Background}

The inflammatory markers such as prostaglandin (PG) $\mathrm{E}_{2}$ nitric oxide (NO), tumor necrosis factor- $\alpha$ (TNF- $\alpha$ ), and interleukins (ILs) play important role in chronic inflammatory diseases. Inflammation is mediated by several transcriptional factors, including NF- $\mathrm{BB}, \mathrm{CREB}, \mathrm{C} / \mathrm{EBP} \beta$ and AP-1, through the activation of multiple signaling pathways; for example, NF-kB, MAPK ERK1/2, p38 and PI3K pathways (reviewed in [1]).

In the presence of a stimulus, such as lypopolysaccharide (LPS), the innate immune response is triggered via activation of the NF- $\kappa B$ pathway: activation of IкB kinase (IKK) complex leads to phosphorylation of IкB and causes the degradation of the complex, which permits the dissocia-

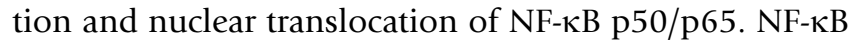
in the nucleus binds to DNA and activates inflammatory genes and proteins. Alternatively, independent of IKK activation, phosphorylation of NF- $\kappa B$ p 65 at serine 468 by glycogen synthase kinase (GSK)-3 $\beta$ also activates the NF$\kappa \mathrm{B}$ pathway, and the inhibition of GSK-3 $\beta$ has been shown to ameliorate inflammation $[2,3]$. In addition, gene knockout mice of NF- $\kappa B$ p 65 or GSK-3 $\beta$ showed similar phenotype and embryonic lethality caused by liver degeneration $[4,5]$, suggesting that they share a common pathway. Hence, the current development of compounds/ drugs to treat inflammatory diseases (e.g. rheumatoid arthritis, or RA) has been targeting the GSK-3/NF- $\mathrm{kB}$ pathway.

Rho iso-alpha acids (RIAA) are a modified extract from hops (Humulus lupulus) that has self-affirmed GRAS (generally regarded as safe) status as determined by an expert panel and used as flavoring/bittering agents in the brewing industry throughout the globe. Our past research suggested that RIAA had anti-inflammatory potential; RIAA dose-dependently inhibited $\mathrm{PGE}_{2}$ production in LPS-stimulated RAW 264.7 macrophages and reduced knee arthritic pain in humans with no reported serious adverse effects $[6,7]$. In addition, in contrast to nonsteroidal antiinflammatory drugs (NSAIDs), RIAA inhibited inducible but not constitutive cyclooxygenase (COX)-2 in vitro; and in human studies, RIAA showed no effect on fecal calprotectin and urinary $\mathrm{PGI}_{2}$, markers used to assess gastrointestinal and cardiovascular complications [6]. Furthermore, animal oral toxicology data reveal that an RIAA-containing product (45\% RIAA of $250 \mathrm{mg} / \mathrm{kg} /$ day) for 21 days showed no adverse effects in mice [8]. These results indicate that RIAA have safer, therapeutic potential to address inflammation.

To understand the anti-inflammatory mechanisms, we evaluated the effects of RIAA in cell signaling pathways and inflammatory markers using various in vitro models. We also investigated the therapeutic effects of RIAA in mice with collagen-induced arthritis (CIA).

\section{Materials and methods Materials}

RIAA was supplied by Hopsteiner (New York, NY); the chemical composition of RIAA was described in [6]. Phospho-ERK1/2, phospho-p38, phospho-JNK, phospho- $\beta$ catenin anti-bodies were purchased from Cell Signaling Technology (Danvers, MA). SB216763 was purchased from Biomol (Plymouth Meeting, PA). LPS (from E. coli), anti-actin antibody, parthenolide and other analytical grade chemicals were purchased from Sigma (St. Louis, $\mathrm{MO}$ ). Electrophoresis gels and reagents were purchased from Bio-Rad (Hercules, CA).

\section{Cell culture}

RAW 264.7 macrophages were purchased from ATCC (Manassas, VA) and maintained in Dulbecco's Modified Eagle's Medium (DMEM) in the presence of $10 \%$ fetal bovine serum (FBS), $100 \mathrm{U}$ penicillin/ml and $100 \mu \mathrm{g}$ streptomycin/ml, according to manufacturer instructions. All test compounds were dissolved in DMSO, then diluted in serum-free media and used at a final concentration of $0.1 \%$ DMSO.

\section{Electrophoretic mobility shift assays (EMSA)}

RAW 264.7 cells were sub-cultured and grown overnight in 6-well plates at a density of $2 \times 10^{6}$ cells per well, and incubated in the absence or presence of RIAA for $1 \mathrm{~h}$ followed by LPS $(1 \mu \mathrm{g} / \mathrm{ml})$ stimulation for $2 \mathrm{~h}$. Nuclear extract was prepared as previously described [9] with modifications. Briefly, cells were lysed with lysis buffer containing $10 \mathrm{mM}$ Hepes-KOH (pH 7.9), 0.1\% NP-40, 10 $\mathrm{mM} \mathrm{KCl}, 1.5 \mathrm{mM} \mathrm{MgCl}_{2}$, and protease inhibitor cocktail (Amersham Biosciences, Piscataway, NJ) for 15 min on ice and centrifuged at $10,000 \times$ for $10 \mathrm{~min}$. Cell pellet was washed with the lysis buffer, resuspended in nuclear extract buffer containing $20 \mathrm{mM}$ Hepes-KOH, 25\% glycerol (v/v), $1.5 \mathrm{mM} \mathrm{MgCl}_{2}, 420 \mathrm{mM} \mathrm{NaCl}, 0.2 \mathrm{mM}$ EDTA and protease inhibitor cocktail, and sonicated $(2 \times 10 \mathrm{sec}$ at $60 \%$ power level). The samples were centrifuged at $10,000 \times$ for $10 \mathrm{~min}$ and the nuclear extract was stored at $80^{\circ} \mathrm{C}$ until analysis. For DNA binding activity, $5 \mu \mathrm{g}$ of the nuclear extract was incubated with $\sim 3 \times 10^{4} \mathrm{cpm}$ of [32P]ATP -labeled NF-кB consensus oligonucleotide (5'AGTTGAGGGGACTTTCCCAGGGC) at room temperature for $20 \mathrm{~min}$. This EMSA probe has been previously shown to be specific for NF- $\mathrm{KB}$ [10]. Following electrophoresis at on $5 \%$ nondenaturing acrylamide gel, the gel was dried and exposed to X-ray film and developed by autoradiography.

\section{Western blot analysis}

RAW 264.7 cells were grown overnight in 12-well plates at a density of $10^{6}$ cells per well, serum starved for $5 \mathrm{~h}$, and incubated with various concentrations of RIAA for $1 \mathrm{~h}$. Cells were washed with PBS and lysed in lysis buffer containing $0.1 \%$ Triton X-100, $20 \mathrm{mM}$ Tris (pH 8.0), $100 \mathrm{mM}$ 
$\mathrm{KCl}, 1 \mathrm{mM}$ DTT, $1 \mathrm{mM}$ PMSF and protease inhibitor cocktail. Total cell lysates were electrophoresed, and incubated overnight at $4{ }^{\circ} \mathrm{C}$ with primary antibodies of phospho $\beta$ catenin (Ser33/37), phospho-ERK1/2 (Thr202/Tyr204), phospho-p38 (Thr180/Tyr182) and phosphor-JNK (Thr183/Tyr185). These antibodies have been shown previously to be specific [11]. Secondary antibody linked to horseradish peroxidase (Amersham Biosciences) was incubated for $1 \mathrm{~h}$ at room temperature, after which proteins were visualized using the enhanced chemiluminescence (ECL) system from Pierce (Rockford, IL). For the loading control, the membranes were stripped and the blot analyzed by using anti-actin antibody.

\section{NF- $\kappa$ B driven luciferase activity}

RAW 264.7 cells were sub-cultured in 96-well plates at a density of $7 \times 10^{4}$ cells per well and transiently transfected using SuperFect transfection reagent with an NF- $\kappa \mathrm{B}$ or cAMP-responsive-element (CRE) firefly luciferase construct (SuperArray, Frederick, MD). After 2 days, cells were pre-incubated with various concentrations of RIAA or the NF- $\kappa \mathrm{B}$ inhibitor parthenolide $(10 \mu \mathrm{M})$ for $1 \mathrm{~h}$ in serumfree media, followed by $8 \mathrm{~h}$ LPS $(1 \mu \mathrm{g} / \mathrm{ml})$ stimulation. Luciferase activity was measured using Dual-Luciferase ${ }^{\circledR}$ Reporter Assay System (Promega, Madison, WI) per the manufacturer's instructions. Transfection was normalized with constitutively expressing Renilla luciferase.

\section{Kinase assays}

Kinase assays were performed at the Upstate Biotechnology (Dundee, UK). Briefly, GSK-3 $\alpha / \beta$ activity was measured in the absence or presence of RIAA. In a final reaction volume of $25 \mu$ l the kinase of interest (5-10 mU) was incubated with $20 \mu \mathrm{M}$ peptide substrate (YRRAAVPPSPSLSRHSSPHQS(p)EDEEE), $10 \mathrm{mM}$ MgAcetate and $[\gamma$ 33P-ATP] (specific activity approximately $500 \mathrm{cpm} / \mathrm{mM}$ ) in the presence of $8 \mathrm{mM}$ MOPS (pH 7.0) and $0.2 \mathrm{mM}$ EDTA. The reaction was initiated by the addition of the $10 \mu \mathrm{M}$ MgATP mix. After 40 min of incubation at room temperature, the reaction was stopped by the addition of $5 \mu \mathrm{l}$ of a $3 \%$ phosphoric acid solution. $10 \mu \mathrm{l}$ of the reaction was then spotted onto a P30 filtermat and washed 3 times for $5 \mathrm{~min}$ in $50 \mathrm{mM}$ phosphoric acid and once in methanol prior to drying and scintillation counting. Detailed protocols are available online (at http://www.millipore.com/ drugdiscovery/dd3/assayprotocols).

\section{Nitrite/Nitrate}

RAW 264.7 cells were sub-cultured overnight in 96-well plates at a density of $7 \times 10^{4}$ cells per well and incubated with various concentrations of RIAA for $1 \mathrm{~h}$ in serum-free media, followed by overnight LPS $(1 \mu \mathrm{g} / \mathrm{ml})$ stimulation. Nitrate/nitrite levels in the medium were measured using the Fluorometric Assay Kit (Cayman Chemical, Ann Arbor, MI) per the manufacturer's instructions.

\section{Osteoclastogenisis and tartrate-resistant acid phosphatase (TRAP) activity}

RAW 264.7 cells were sub-cultured in 48-well plates at a density of $7 \times 10^{4}$ cells per well and incubated with various concentrations of RIAA in medium at a final concentration of $0.1 \%$ DMSO. Following overnight incubation, $50 \mathrm{ng} / \mathrm{ml}$ of soluble receptor activator of NF- $\mathrm{B}$-ligand (sRANKL) was added. After 2 days, medium and all reagents were replaced and incubation was continued for 3 more days. Cells were washed with ice cold PBS, lysed in $150 \mu \mathrm{l}$ of $0.2 \%$ Triton X-100 in PBS, and TRAP activity was determined using a TRAP Kit from Sigma (Cat. \#387A1). Briefly, $100 \mu \mathrm{l}$ lysate was added to $100 \mu \mathrm{l}$ of TRAP solution and incubated at $37^{\circ} \mathrm{C}$ for $1 \mathrm{~h}$ followed by measurement of absorbance at $555 \mathrm{~nm}$. Protein concentration was estimated using BCA reagent (Bio-Rad) and final activity was normalized for equal protein.

\section{Chondrocytes and matrix metalloproteinase (MMP)- I3 expression}

The human chondrosarcoma cell line SW1353 was purchased from ATCC and maintained in L-15 medium in the presence of $10 \%$ FBS, according to manufacturer instructions. Cells were sub-cultured overnight in 96-well plates at a density of $8 \times 10^{4}$ cells per well. Following $1 \mathrm{~h}$ of incubation with various concentrations of RIAA, TNF- $\alpha$ or IL-1 $\beta$ (10 ng/ml) was added for 20-24 h and MMP-13 levels measured in medium using an ELISA kit (Amersham Biosciences), according to the manufacturer's instructions.

\section{Animal study}

The study was performed at the Washington Biotechnology, Inc. (Simpsonville, MD) laboratories with approved standard protocol (CIA-MI). (i) Induction of collageninduced arthritis: $6.5 \mathrm{ml}$ of bovine type II collagen was emulsified with an equal volume of Complete Freund's Adjuvant (CFA, Chondrex, Redmond, WA, $4 \mathrm{mg} / \mathrm{ml}$ ). Female DBA/1J mice (6-7 weeks) [2] were injected subcutaneously at the base of the tail with $50 \mu$ of the emulsion (containing $100 \mu \mathrm{g}$ type II collagen), with a booster injection after 21 days. After 7 days, mice that developed arthritis were used for the study. (ii) Experimental groups: Each group consists of 10 animals for (1) vehicle treatment $50 \mu \mathrm{l}$ distilled water/CFA emulsion, (2) celecoxib - 20 $\mathrm{mg} / \mathrm{kg}$, (3-5) RIAA - 250, 50 and $10 \mathrm{mg} / \mathrm{kg}$, respectively, and (6) the "non-diseased" control. Test agents in $2 \%$ Tweeen-80 were administered daily by gavage $(10 \mathrm{ml} / \mathrm{kg})$. Treatment continued for 14 days and the arthritic index determined every other day. (iii) Determination of the arthritic index: Each paw was evaluated on the basis of a 4-point ordinal scale: 0 - no visible signs, 1 - edema/erythema of a single joint or digit; 2 - edema/erythema of 2 joints; 3 - edema/erythema of $>2$ joints; 4 - severe arthritis of the entire paw and digits accompanied by ankylosis 
A

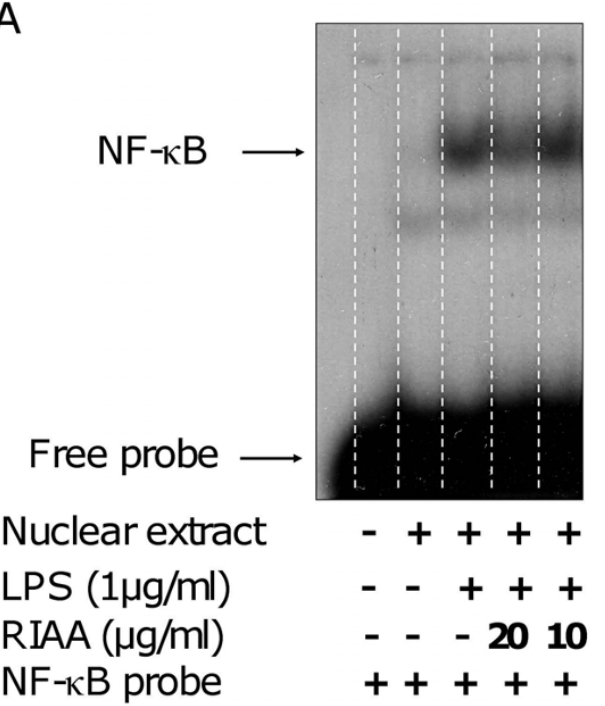

C

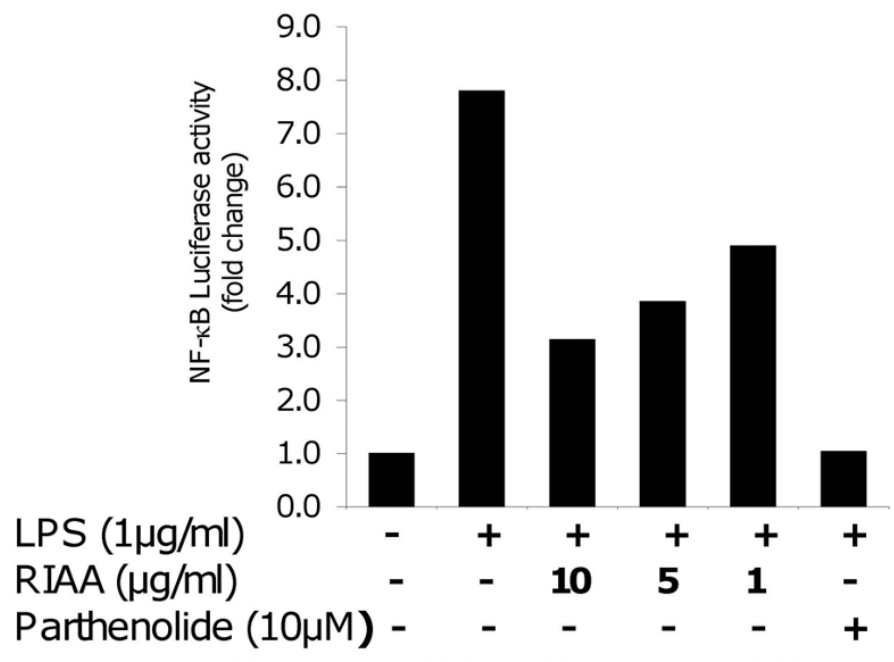

B

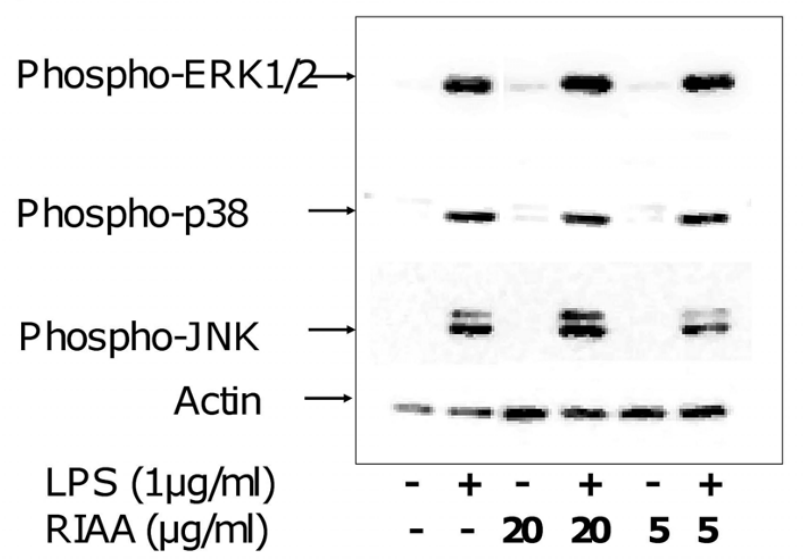

D

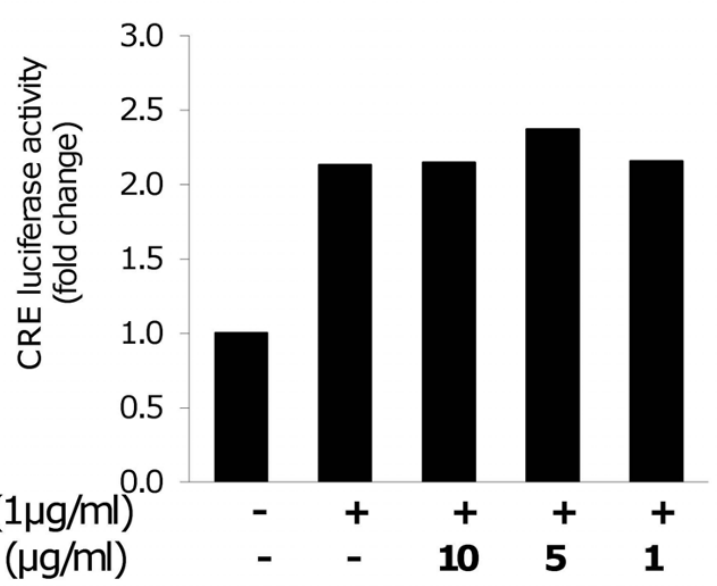

\section{Figure I}

Effect of RIAA on LPS-induced inflammatory signaling pathways in RAW 264.7 cells. (A) Cells were incubated for I h with RIAA $(0,10$ and $20 \mu \mathrm{g} / \mathrm{ml})$ followed by LPS stimulation $(\mathrm{I} \mu \mathrm{g} / \mathrm{ml})$ for $2 \mathrm{~h}$. Nuclear extract were analyzed for NF- $\mathrm{B}$ binding by EMSA. (B) Cells were pre-incubated with RIAA (5 and $20 \mu \mathrm{g} / \mathrm{ml}$ ) for I h and stimulated with LPS (I $\mu \mathrm{g} / \mathrm{ml})$ for I h. Cell lysates were analyzed for phosphorylation of ERKI/2, p38 and JNK using western blot. (C) Cells transiently transfected with NF- $\kappa$ B firefly luciferase construct were incubated with RIAA (I, 5 and $10 \mu \mathrm{g} / \mathrm{ml})$ or NF- $\kappa$ B inhibitor parthenolide (I0 $\mu$ M) for I $\mathrm{h}$ followed by LPS (I $\mu \mathrm{g} / \mathrm{ml})$ stimulation for $8 \mathrm{~h}$. The luciferase activities were determined and normalized with Renilla expression, and expressed as fold change compared to vehicle control. Data shown is representative of the experiment repeated several times. (D) Cells transiently transfected with CRE firefly luciferase construct were incubated with RIAA (I, 5 and $10 \mu \mathrm{g} / \mathrm{ml})$ for I $\mathrm{h}$ followed by LPS $(\mathrm{I} \mu \mathrm{g} / \mathrm{ml})$ stimulation for $8 \mathrm{~h}$. The luciferase activities were determined and corrected with Renilla expression, and expressed as fold change compared to vehicle control. Data shown is representative of the experiment repeated several times.

of the ankle and limb deformity. The index was calculated by summing from all four paws with a maximum score of 16. (iv) Histological evaluation: At day 42, mice were euthanized. One limb from each mouse was removed and preserved in $10 \%$ buffered formalin, decalcified, and sub- sequently trimmed so as to render a longitudinal section through the limb and digits. The specimens were processed, blocked, sectioned, stained with Haematoxylin and Eosin for microscopic examination. Soft tissue, bone and joint changes were evaluated using a standardized severity 
score whereby $0=$ not present, $1=$ minimal, $2=\operatorname{mild}, 3=$ moderate and $4=$ severe.

\section{Statistical analysis}

SAS 9.0 (Cary, NC) was used for the statistical analyses. The in vitro data (NO inhibition, TRAP activity and MMP13 inhibition) and the in vivo data (arthritis index and histological index) were analyzed using one-way ANOVA with Dunnett's post-hoc multiple comparisons in which the treatment groups were compared to the positive control; data are expressed as mean \pm SEM. The significance level was at 0.05 . No statistical tests were performed on data from a single experiment.

\section{Results}

Effects of RIAA on signaling pathways in LPS-stimulated RAW 264.7 macrophages

First, the effect of RIAA on NF- $\kappa$ B in vitro was investigated. RAW 264.7 cells were treated with LPS alone $(1 \mu \mathrm{g} / \mathrm{ml})$ or RIAA (10 and $20 \mu \mathrm{g} / \mathrm{ml}$ ) followed by LPS incubation. Nuclear extracts were then analyzed by EMSA. RIAA at 20 $\mu \mathrm{g} / \mathrm{ml}$ inhibited NF- $\kappa \mathrm{B}$ to its consensus sequence as evidenced by reduced band intensity (Fig. 1A, lane 4). Next, the effect of RIAA on MAPK was investigated. Western blot analysis of total extract showed that, in the presence or absence of LPS stimulation, RIAA (5 and $20 \mu \mathrm{g} / \mathrm{ml}$ ) had no effects on phosphorylation of ERK1/2, p38 and JNK in RAW 264.7 cells (Fig. 1B). Next, RAW cells were transfected with either NF- $\kappa B$ or CRE firefly luciferase construct, treated without or with RIAA $(1,5$ and $10 \mu \mathrm{g} / \mathrm{ml})$, and followed by LPS $(1 \mu \mathrm{g} / \mathrm{ml})$ stimulation. The luciferase reporter assays revealed that RIAA inhibited transactiva- tion of NF- $\kappa B$ (Fig. 1C), but had no effects on that of CRE (Fig. 1D).

\section{Effects on the GSK-3 signaling pathway}

GSK-3 $\alpha / \beta$ kinase activities were evaluated in the absence or presence of RIAA $(1-50 \mu \mathrm{g} / \mathrm{ml})$ in cell-free kinase assays. We found that RIAA dose-dependently inhibited both kinases (Fig. 2A and 2B). We also measured phosphorylation of $\beta$-catenin, a known GSK-3 substrate, in RAW 264.7 cells by western blotting. Cells treated with RIAA for $1 \mathrm{~h}$ inhibited $\beta$-catenin phosphorylation (Fig. 2C).

\section{Effects on inflammatory markers associated with the NF- «B pathway}

We investigated whether RIAA affected various inflammatory markers using established in vitro cell models $[6,12,13]$. First, in LPS-stimulated RAW 264.7 cells we found that RIAA dose-dependently inhibited NO levels, particularly at 10 and $20 \mu \mathrm{g} / \mathrm{ml}$ (Fig. 3A). Second, in RANKL-transformed osteoclasts/RAW cells, RIAA at 10 $\mu \mathrm{g} / \mathrm{ml}$ inhibited TRAP activity (Fig. 3B). Third, in SW1353 cells, RIAA at 10 and $20 \mu \mathrm{g} / \mathrm{ml}$ inhibited TNF- $\alpha$ mediated MMP-13 secretion in a dose-dependent manner (Fig. 3C), and RIAA at 5, 10 and $20 \mu \mathrm{g} / \mathrm{ml}$ inhibited IL- $1 \beta$ mediated MMP-13 secretion (Fig. 3D).

\section{Inhibition on arthritis index in CIA model}

Mice with CIA were orally fed 10, 50, or $250 \mathrm{mg} / \mathrm{kg}$-bodyweight of RIAA, and symptoms of joint swelling were measured daily for 14 days and the arthritic index was calculated. We found that RIAA dose-dependently reduced
A

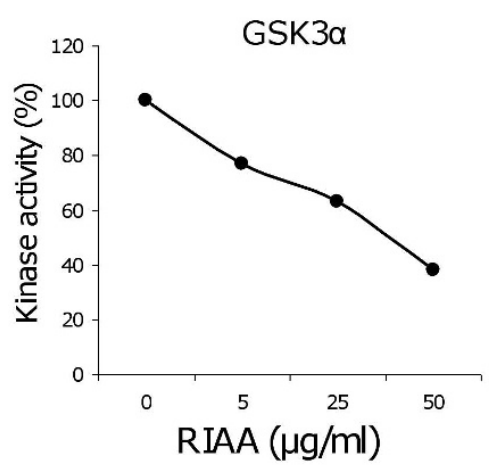

B

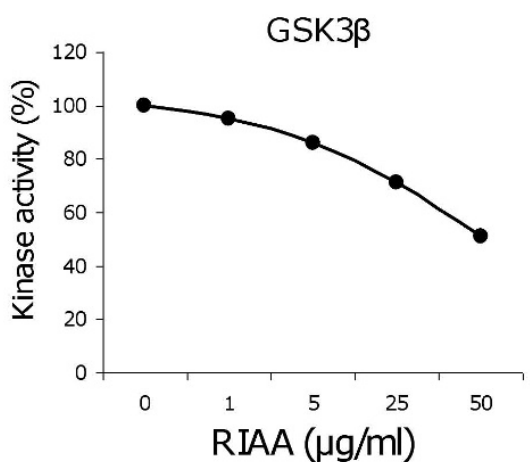

C

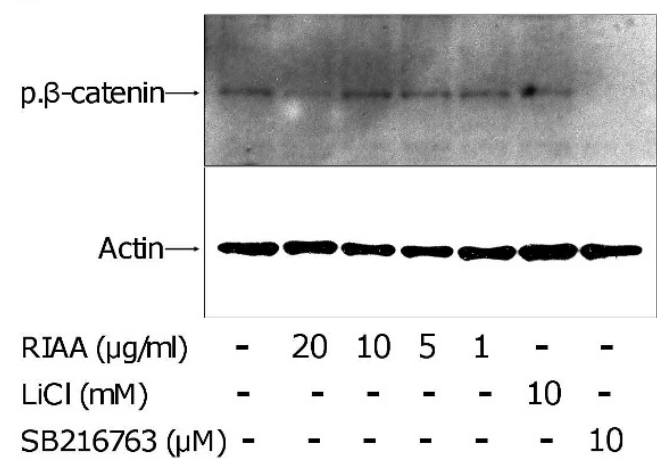

Figure 2

Effect of RIAA on the inhibition of GSK3 pathway. (A) GSK- $3 \alpha$ was incubated with RIAA (0, 5, 25 and $50 \mu g / m l)$ and the kinase activity was determined. Data represent I representative experiment and are expressed as \% activity. (B) GSK-3 $\beta$ was incubated with RIAA $(0, I, 5,25$ and $50 \mu \mathrm{g} / \mathrm{ml})$ and the kinase activity was determined. Data represent I representative experiment and are expressed as \% activity. (C) RAW 264.7 cells were incubated with RIAA (0, I, 5, I0 and $20 \mu \mathrm{g} / \mathrm{ml})$, or GSK-3 inhibitors $\mathrm{LiCl}(10 \mathrm{mM})$ and SB2 I6763 (I0 $\mu \mathrm{M})$ for I h. Cell lysates were analyzed for the inhibition of phosphorylation of $\beta$ catenin by western blot. 
the arthritis index, and at $250 \mathrm{mg} / \mathrm{kg}$, their efficacy was similar to that of $20 \mathrm{mg} / \mathrm{kg}$ of celecoxib, the positive control (Fig. 4A). Joints from the animals were also evaluated histologically. RIAA at $250 \mathrm{mg} / \mathrm{kg}$ significantly reduced the histological index, but not celecoxib (Fig. 4B). Analyses of individual markers revealed that, compared to the diseased controls, animals receiving RIAA (250 mg/kg) showed significant reduction in joint destruction $(1.90 \pm$ 0.43 vs. $0.20 \pm 0.20, P<0.001)$, cartilage degradation
$(2.65 \pm 0.26$ vs. $1.85 \pm 0.15, \mathrm{P}=0.003)$ and bone erosion $(2.65 \pm 0.15$ vs. $1.75 \pm 0.17, \mathrm{P}=0.002)$.

\section{Discussion}

Inflammatory diseases such as RA are predominantly treated with NSAIDs or selective COX-2 inhibitors. Due to their well-known adverse effects in the gastrointestinal and cardiovascular systems when they are used long-term, researchers have been seeking novel candidates with safer

A

C
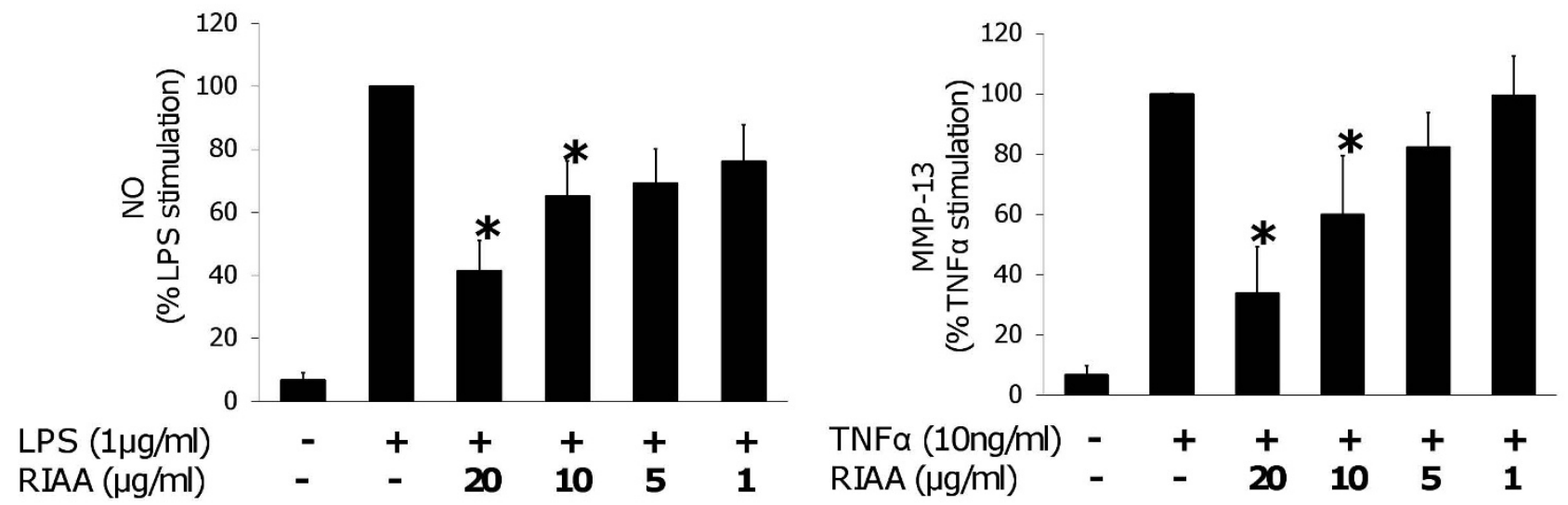

B
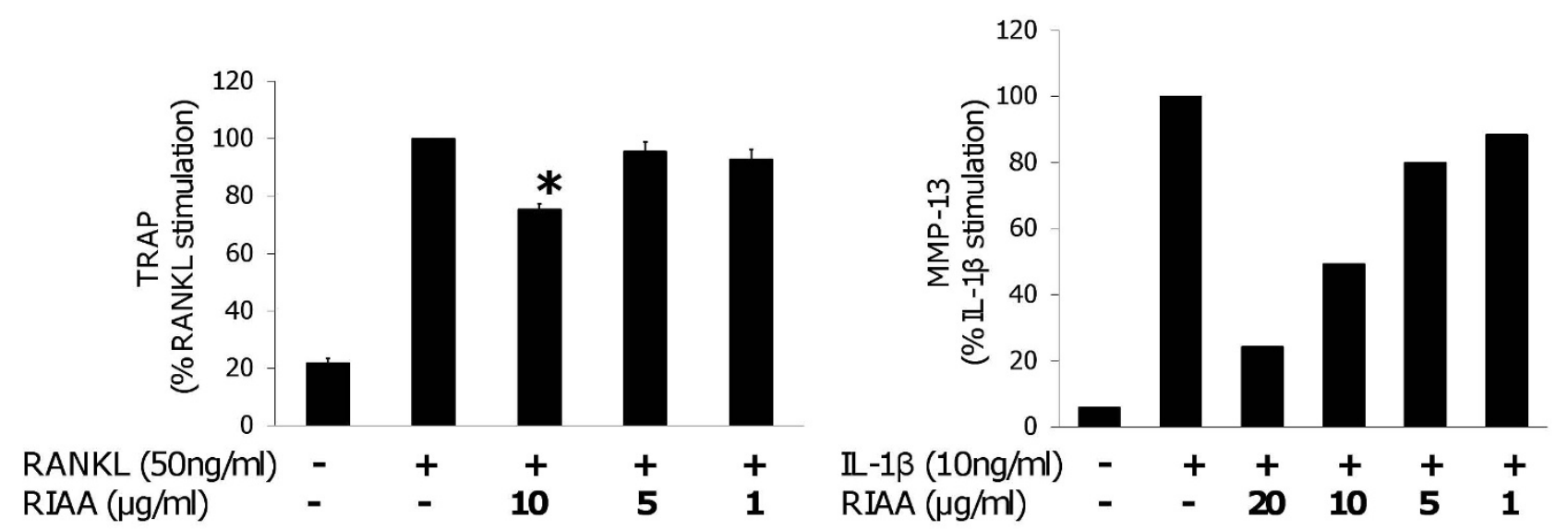

Figure 3

Effect of RIAA on the inhibition of inflammatory markers. (A) RAW 264.7 cells were incubated with vehicle or RIAA $(\mathrm{I}, 5,10$ and $20 \mu \mathrm{g} / \mathrm{ml})$ for I h and subsequently stimulated with LPS $(\mathrm{I} \mu \mathrm{g} / \mathrm{ml})$ overnight. Nitrite/nitrate levels were measured in the medium and expressed as $\%$ activity over LPS stimulation. Data represent mean \pm SEM $(n=6)$. (B) RAW cells were pretreated with vehicle or RIAA (I, 5 and $10 \mu \mathrm{g} / \mathrm{ml})$ overnight and stimulated with RANKL (50 ng/ml) for transformation to osteoclasts for 5 days. TRAP activity was measured in the cell lysate and expressed as \% activity over RANKL stimulation. Data represent mean \pm SEM $(n=6)$. (C) SWI 353 cells were incubated with vehicle or RIAA $(I, 5,10$ and $20 \mu \mathrm{g} / \mathrm{ml})$ for I h and stimulated with TNF- $\alpha$ (I0 ng/ml) for 20-24 h. MMP-I 3 levels were measured in the medium and expressed as \% activity over TNF- $\alpha$ stimulation. Data represent mean \pm SEM $(n=5)$. *a significant difference $(P<0.05)$ in $\%$ activity compared to the respective positive control after Dunnett post-hoc adjustment. (D) Protocol same as (C) except IL-I $\beta$ (I0 ng/ml) was used instead of TNF- $\alpha$. Data shown is that of a single experiment. 
modes of action. We found RIAA to be a promising antiinflammatory candidate as it did not negatively impact gastrointestinal and cardiovascular biomarkers (e.g. fecal calprotectin and PGI-M/TXB 2 ratio) commonly associated with NSAIDs [6]. To gain further understanding of RIAA's anti-inflammatory mechanism (s), we evaluated its effects on cell signaling pathways and in vitro inflammatory markers. We examined the effects of RIAA on NF- $\kappa$ B and MAPK in RAW 264.7 macrophages because these pathways activate transcriptional and post-transcriptional factors that upregulate pro-inflammatory genes, enzymes and cytokines $[1,14,15]$. We found that RIAA inhibited the LPS-activated nuclear NF- $\kappa \mathrm{B}$ binding to its consensus sequence, which indicated a reduction in nuclear abundance of NF- $\kappa \mathrm{B}$ (Fig. 1A). In addition, RIAA dose-dependently reduced the LPS-induced-transcriptional activity of NF- $\kappa \mathrm{B}$ (Fig. 1C). On the other hand, RIAA did not affect the phosphorylation of ERK1/2, p38 and JNK in RAW cells (Fig. 1B), nor the transactivation of CRE (Fig. 1D), a known transcriptional factor regulated by MAPK in LPSactivated macrophages [16]. The data demonstrated that
RIAA specifically inhibited NF- $\kappa \mathrm{B}$ signaling pathway but not MAPK pathways.

In general, the activation of $\mathrm{NF}-\kappa \mathrm{B}$ is regulated at several levels, including IKK-mediated I $\mathrm{I} B$ degradation and nuclear translocation and DNA binding. During our screening we found that RIAA did not inhibit IKK (data now shown). Alternatively, post-translational modification of NF- $\kappa \mathrm{B}-\mathrm{p} 65$ regulates the function of NF- $\kappa \mathrm{B}$ $[3,17,18]$; and through the p65 subunit, GSK-3 has been shown to regulate the production of pro-inflammatory cytokines. Therefore, we investigated the effects of RIAA on the GSK-3 signaling pathway. Both GSK-3 $\alpha$ and GSK$3 \beta$ were inhibited by RIAA (Fig. $2 \mathrm{~A}$ and $2 \mathrm{~B}$ ), and phosphorylation of a known GSK-3 substrate, $\beta$-catenin, was inhibited by RIAA in RAW 264.7 cells (Fig. 2C). This mode of action is similar to a known GSK-3 inhibitor, SB216763, which also inhibited $\beta$-catenin [19]. It has been shown that $\beta$-catenin plays a significant anti-inflammatory role by reducing NF- $\kappa \mathrm{B}$ activity [20]. Therefore, our data suggested that the anti-inflammatory mechanism
A

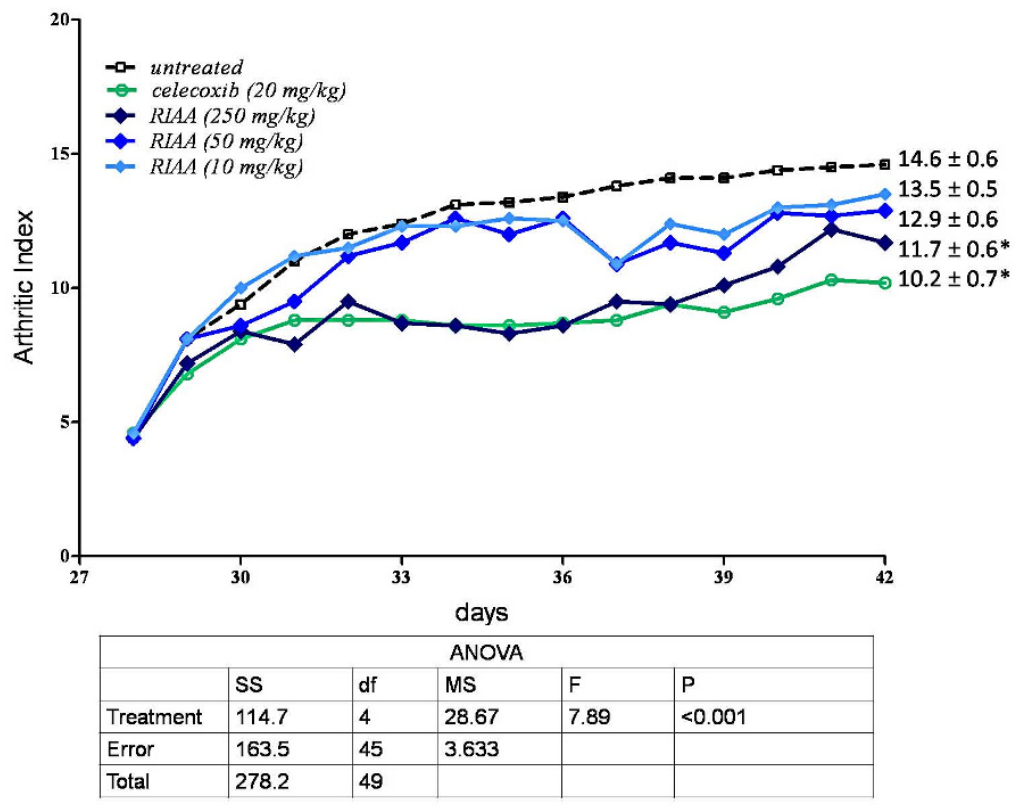

B

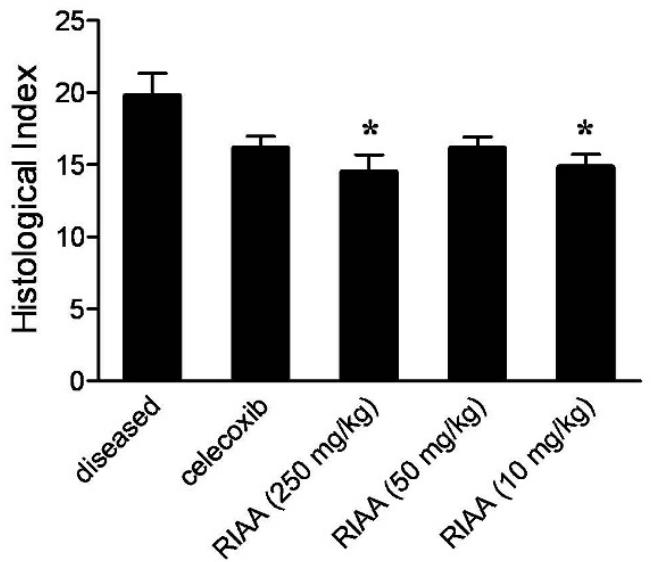

\section{Figure 4}

Effect of RIAA in mice model of CIA. The DBA/IJ mice were injected intradermally with $100 \mu \mathrm{g}$ of bovine type II collagen. After $2 \mathrm{I}$ days the mice were given a booster dose. CIA was fully developed at day 28 when treatments initiated and continued for the next 14 days. The arthritis index was assessed every other day. (A) The mean arthritis index for 3 RIAA treatment groups ( 10,50 and $250 \mathrm{mg} / \mathrm{kg}$ body weight), celecoxib-treated group ( $20 \mathrm{mg} / \mathrm{kg}$ body weight) and the vehicle-treated control group. Day 42 data are expressed as mean \pm SEM. Mice in the non-diseased group had an arthritis index of 0 throughout the experiment and therefore the data points were not displayed. (B) After evaluation of the arthritis index was completed at day 42, mice were anesthetized, and a histological examination was performed in 3 RIAA treatment groups, celecoxib-treated group and the vehicle-treated group (mean $\pm S E M)$. *a significant difference $(P<0.05)$ in histology score compared to diseased control after Dunnett post-hoc adjustment. 
of RIAA involves the inhibition of GSK-3/NF- $\mathrm{KB}$ pathway. Future assessment of the inhibition of $\beta$-catenin phosphorylation in vivo will further strengthen our in vitro finding.

We proceeded to investigate whether RIAA affected NF$\kappa \mathrm{B}$-mediated pro-inflammatory mediators in various in vitro models, and found that it inhibited NO in LPS-stimulated RAW 264.7 cells; RANKL-mediated TRAP activity in transformed osteoclasts; and TNF- $\alpha /$ IL-1 $\beta$-mediated MMP-13 expression in SW1353 human chondrosarcoma cells. It has been demonstrated that $\mathrm{NO}$ is involved in the pathogenesis of arthritis [21,22]; enhanced TRAP activity of osteoclasts increases bone resorption and contributes to bone loss [23]; and IL-1/TNF- $\alpha$ stimulate chondrocytes to increase production of MMPs and other degradative products [24-26]. These mediators cause bone erosion and cartilage degradation, and result in joint damage in RA [27]. Interventions targeting one or more of these mediators have been reported to reduce inflammation and degree of severity of RA, osteoarthritis and osteoporosis [23-25]; therefore, we tested the therapeutic effect of RIAA in mice with CIA. Two weeks of oral administration of RIAA at $250 \mathrm{mg} / \mathrm{kg}$-body weight ameliorated joint damage in these mice as evidenced by significant reductions in the arthritis index and histology score. We found that the efficacy in reducing the arthritis index at this dose was similar to that of $20 \mathrm{mg} / \mathrm{kg}$-body weight of celecoxib. Interestingly, however, celecoxib did not significantly reduce the histology score. This is likely due to the fact that celecoxib inhibits COX-2-mediated $\mathrm{PGE}_{2}$ synthesis evidenced by the reduced arthritis index, but does not inhibit NF- $\mathrm{BB}$, an important mediator for bone and cartilage degradation.

Kinase inhibitors have shown beneficial effects in preclinical or clinical trials or in animal disease models for the treatment of cancer and autoimmune diseases $[19,28,29]$. For instance, GSK-3 $\beta$ inhibitors TDZD- 8 and SB216763 reduced NF- $\kappa B$ mediated inflammation in rats with endotoxemia, and protected tissue damage in CIA mice. Our data demonstrated that RIAA inhibited GSK-3 $\beta /$ NF- $\mathrm{KB}$ mediated signaling pathways and inflammation, and reduced RA symptoms in CIA mice, suggesting that RIAA may have potential as an anti-inflammatory therapeutic.

\section{Competing interests}

The study was funded by MetaProteomics, LLC, a subsidiary of Metagenics, Inc. that manufactures the commercial medical food for licensed healthcare professionals. All authors are employees of MetaProteomics.

\section{Authors' contributions}

All authors participated in the concept and design of the study, and contribute to manuscript preparation. VRK and
$\mathrm{AD}$ carried out the in vitro assays and performed the statistical analyses. GD carried out the animal study. All authors read and approved the final manuscript.

\section{Acknowledgements}

We thank Dr. Jyh-Lurn Chang for preparing the manuscript and Alex Hsi for statistical analyses.

\section{References}

I. Guha M, Mackman N: LPS induction of gene expression in human monocytes. Cell Signal 200 I, I 3:85-94.

2. Cuzzocrea S, Mazzon E, Di Paola R, Muia C, Crisafulli C, Dugo L, Collin M, Britti D, Caputi AP, Thiemermann C: Glycogen synthase kinase-3beta inhibition attenuates the degree of arthritis caused by type II collagen in the mouse. Clin Immunol 2006, I 20:57-67.

3. Gong R, Rifai A, Ge Y, Chen S, Dworkin LD: Hepatocyte growth factor suppresses proinflammatory NFkappaB activation through GSK3beta inactivation in renal tubular epithelial cells. J Biol Chem 2008, 283:740I-74I0.

4. Beg AA, Sha WC, Bronson RT, Ghosh S, Baltimore D: Embryonic lethality and liver degeneration in mice lacking the RelA component of NF-kappa B. Nature 1995, 376:167-I70.

5. Hoeflich KP, Luo J, Rubie EA, Tsao MS, Jin O, Woodgett JR: Requirement for glycogen synthase kinase-3beta in cell survival and NF-kappaB activation. Nature 2000, 406:86-90.

6. Hall AJ, Babish JG, Darland GK, Carroll BJ, Konda VR, Lerman RH, Bland JS, Tripp ML: Safety, efficacy and anti-inflammatory activity of rho iso-alpha-acids from hops. Phytochemistry 2008 , 69:1534-1547.

7. Tripp M, Darland G, Lerman R, Lukaczer D, Bland J, Babish J: Hop and modified hop extracts have potent in vitro anti-inflammatory properties. Acta Hort (ISHS) 2005, 668:217-228.

8. Minich DM, Bland JS, Katke J, Darland G, Hall A, Lerman RH, Lamb J, Carroll $B$, Tripp $M$ : Clinical safety and efficacy of NG440: a novel combination of rho iso-alpha acids from hops, rosemary, and oleanolic acid for inflammatory conditions. Can J Physiol Pharmacol 2007, 85:872-883.

9. Reddy KV, Serio KJ, Hodulik CR, Bigby TD: 5-lipoxygenase-activating protein gene expression. Key role of CCAAT/ enhancer-binding proteins (C/EBP) in constitutive and tumor necrosis factor (TNF) alpha-induced expression in THP-I cells. J Biol Chem 2003, 278: I3810-13818.

10. Desai A, Konda VR, Darland G, Austin M, Prabhu KS, Bland JS, Carroll B], Tripp ML: META060 inhibits multiple kinases in the NF. kappaB pathway and suppresses LPS - mediated inflammation in vitro and ex vivo. Inflamm Res 2009, 58:229-234.

II. Luyendyk JP, Piper JD, Tencati M, Reddy KV, Holscher T, Zhang R, Luchoomun J, Chen X, Min W, Kunsch C, Mackman N: A novel class of antioxidants inhibit LPS induction of tissue factor by selective inhibition of the activation of ASKI and MAP kinases. Arterioscler Thromb Vasc Biol 2007, 27:1857-1863.

12. Mix KS, Mengshol JA, Benbow U, Vincenti MP, Sporn MB, Brinckerhoff $C E$ : A synthetic triterpenoid selectively inhibits the induction of matrix metalloproteinases I and I 3 by inflammatory cytokines. Arthritis Rheum 200I, 44:1096-I I04.

13. Rahman MM, Bhattacharya A, Fernandes G: Conjugated linoleic acid inhibits osteoclast differentiation of RAW264.7 cells by modulating RANKL signaling. J Lipid Res 2006, 47: I739-I 748.

14. Newton R, Kuitert LM, Bergmann M, Adcock IM, Barnes PJ: Evidence for involvement of NF-kappaB in the transcriptional control of COX-2 gene expression by IL-I beta. Biochem Biophys Res Commun 1997, 237:28-32.

15. Xie QW, Kashiwabara Y, Nathan C: Role of transcription factor NF-kappa B/Rel in induction of nitric oxide synthase. J Biol Chem 1994, 269:4705-4708.

16. Nemeth ZH, Leibovich SJ, Deitch EA, Sperlagh B, Virag L, Vizi ES, Szabo C, Hasko G: Adenosine stimulates CREB activation in macrophages via a 38 MAPK-mediated mechanism. Biochem Biophys Res Commun 2003, 3 I 2:883-888.

17. Schwabe RF, Brenner DA: Role of glycogen synthase kinase-3 in TNF-alpha-induced NF-kappaB activation and apoptosis in 
hepatocytes. Am J Physiol Gastrointest Liver Physiol 2002, 283:G204-2II.

18. Dugo L, Collin M, Allen DA, Patel NS, Bauer I, Mervaala EM, Louhelainen M, Foster SJ, Yaqoob MM, Thiemermann C: GSK-3beta inhibitors attenuate the organ injury/dysfunction caused by endotoxemia in the rat. Crit Care Med 2005, 33:1903-1912.

19. Martin M, Rehani K, Jope RS, Michalek SM: Toll-like receptormediated cytokine production is differentially regulated by glycogen synthase kinase 3. Nat Immunol 2005, 6:777-784.

20. Duan Y, Liao AP, Kuppireddi S, Ye Z, Ciancio MJ, Sun J: beta-Catenin activity negatively regulates bacteria-induced inflammation. Lab Invest 2007, 87:6 I3-624.

21. Beri A, Singh S, Gupta A, Khullar M: Comparison of serum nitric oxide levels in active juvenile rheumatoid arthritis with those of patients in remission. Rheumatol Int 2004, 24:264-266.

22. Vuolteenaho K, Moilanen T, Hamalainen M, Moilanen E: Effects of TNFalpha-antagonists on nitric oxide production in human cartilage. Osteoarthritis Cartilage 2002, 10:327-332.

23. Redlich K, Hayer S, Ricci R, David JP, Tohidast-Akrad M, Kollias G, Steiner G, Smolen JS, Wagner EF, Schett G: Osteoclasts are essential for TNF-alpha-mediated joint destruction. J Clin Invest 2002, I 1 0:1419-1427.

24. Shi J, Schmitt-Talbot E, DiMattia DA, Dullea RG: The differential effects of IL-I and TNF-alpha on proinflammatory cytokine and matrix metalloproteinase expression in human chondrosarcoma cells. Inflamm Res 2004, 53:377-389.

25. Mitchell PG, Magna HA, Reeves LM, Lopresti-Morrow LL, Yocum SA, Rosner PJ, Geoghegan KF, Hambor JE: Cloning, expression, and type II collagenolytic activity of matrix metalloproteinase- I 3 from human osteoarthritic cartilage. J Clin Invest 1996, 97:761-768.

26. Mengshol JA, Vincenti MP, Brinckerhoff CE: IL-I induces collagenase-3 (MMP-13) promoter activity in stably transfected chondrocytic cells: requirement for Runx-2 and activation by p38 MAPK and JNK pathways. Nucleic Acids Res 200I, 29:436I-4372.

27. Sharp JT, Wolfe F, Mitchell DM, Bloch DA: The progression of erosion and joint space narrowing scores in rheumatoid arthritis during the first twenty-five years of disease. Arthritis Rheum 1991, 34:660-668.

28. Paniagua RT, Sharpe O, Ho PP, Chan SM, Chang A, Higgins JP, Tomooka BH, Thomas FM, Song J], Goodman SB, et al.: Selective tyrosine kinase inhibition by imatinib mesylate for the treatment of autoimmune arthritis. J Clin Invest 2006, I I 6:2633-2642.

29. Karaman MW, Herrgard S, Treiber DK, Gallant P, Atteridge CE, Campbell BT, Chan KW, Ciceri P, Davis MI, Edeen PT, et al: A quantitative analysis of kinase inhibitor selectivity. Nat Biotechnol 2008, 26: 127-132.

Publish with Biomed Central and every scientist can read your work free of charge

"BioMed Central will be the most significant development for disseminating the results of biomedical research in our lifetime. "

Sir Paul Nurse, Cancer Research UK

Your research papers will be:

- available free of charge to the entire biomedical community

- peer reviewed and published immediately upon acceptance

- cited in PubMed and archived on PubMed Central

- yours - you keep the copyright

Submit your manuscript here:

http://www.biomedcentral.com/info/publishing_adv.asp
BioMedcentral 